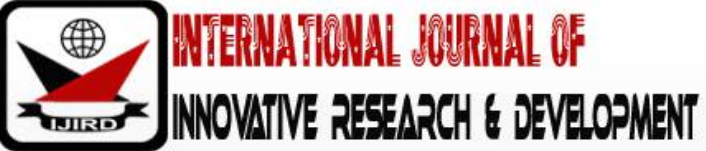

ISSN 2278-0211 (Online)

\section{How Local Empowerment and Environmental Management Project Impacted Control on Rural - Urban Migration in South- East Nigeria with Rural Agricultural Water Delivery Support}

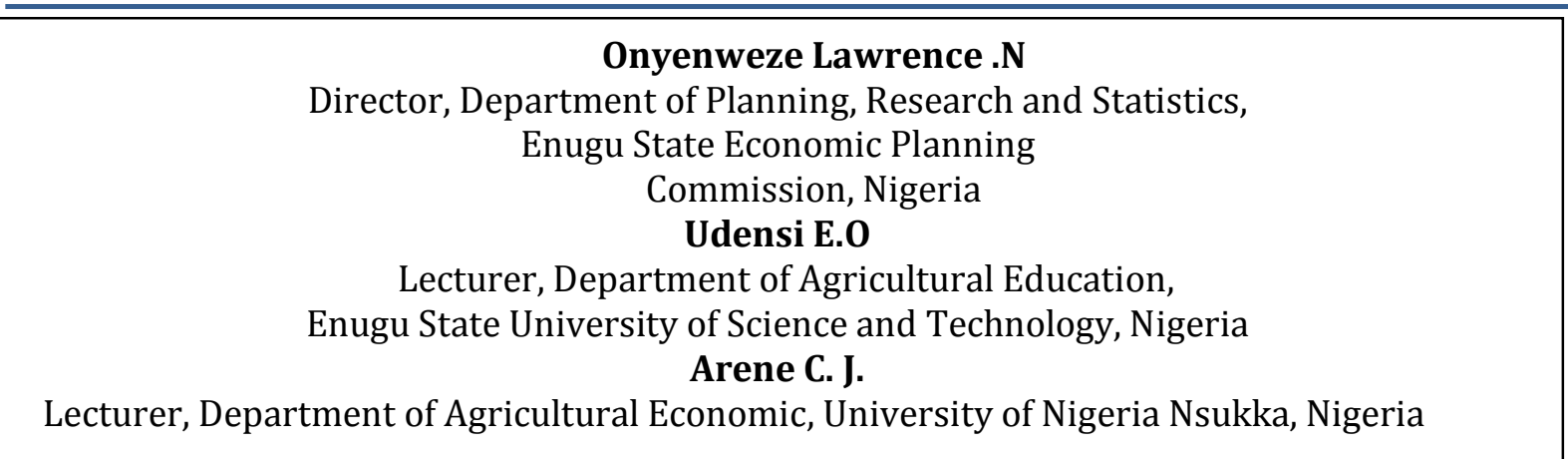

\begin{abstract}
:
This study mainly focused on the impact of rural micro-project water delivery support of Local Empowerment and Environmental Management Project (LEEMP) in controlling rural-urban migration in the southeastern Nigeria. Primary data were used for this study and followed up with the use of simple random sampling technique. One hundred and eighty farmers (180 farmers) were sampled. The total sample was composed of 43\% females and 57\% males. Marginal Analysis Model, Chi-square and regression analysis models were used for the analysis of the data. The result Showed that water delivery support had positive impact in controlling rural urban migration through direct vendible water and through indirect employment opportunities created by investments in fishery and poultry. Timeliness of farm operation was enhanced with availability of potable water and living in the water micro-project beneficiary rural communities was made easy. The LEEMP social safety-net credit and the credit from CDD participating banks in the rural communities favoured poultry enterprises but significantly $(p<0.05)$ had low credit for fishery which is emerging as profitable source of rural income.
\end{abstract}

Keywords: Rural water delivery support of local empowerment and environmental management project; rural - urban migration in South-East Nigeria

\section{Introduction}

In the orientation of rural - urban migration (drift), Nigerian policy on rural-urban migration shows that integration of natural resource management in rural development has significant contribution to make. Removal of dry season water stress with water micro-project support for a greater number of rural communities and their young people who eke their living from agricultural productivity can solve the problem of rural - urban migration to a great extent. Water delivery support of Local Empowerment and Employment Management Project (LEEMP) was chosen by many communities in Southeastern Nigeria as their public good project. Rural man-hours/-days, in water stressed communities, are usually heavily affected by the dry season water stress significantly (Okwor, 2001). Even poultry and fishery also suffer a lot due to seasonal water scarcity. Many youths had shifted to urban from rural setting due to this unhealthy, unproductive environmental challenge due to the associated off -season employment opportunities with its poverty threat. If proper investments can be done in water delivery it can improve rural credit worthiness, rural credit facilities, education enhancement, communication facility, health facilities. LEEMP initially started with 3 local government areas in each LEEMP participating state of Nigerian federation but increased to 18 in 2006, and with only participating southeastern states as Enugu and Imo. The basic mechanism of Community Driven Development (CDD) strategy was adopted by LEEMP (Afatyo, 2005). Community and Social Development Project (CSDP) is the current operational name for LEEMP from March,2009. As an objective LEEMP uses IDA funds to finance micro-project supports for rural communities that chose investments in water delivery. It is predictable that a communal borehole venture would obtain N6.5 million worth of support from LEEMP (Eze, 2005). On entry activities, LEEMP started intervening with micro-project support in states such as Adamawa, Bauchi, Bayelsa, Benue, Enugu, Imo, Katsina, Niger and Oyo (FPSU, 2006). 


\section{Water Poverty and Rural -Urban Migration in Nigeria: An Overview}

In water stressed rural areas, sources of water supply and delivery are problematic. This even has disturbed many training-careers of farmers' children. According to Eze (2007), some of school children often miss their classes, and some even encountered accident by some fast-moving vehicles while searching for water to a long distance (Eze, 2007). He also highlighted that October to April of every year is usually the most dangerous period for the people of Akama Oghe in Ezeagu local government area of Enugu state. Really, it is the period when some shylock tanker drivers seize the opportunity of non-availability of water in the area to milk the people dry. Women, children and even the elderly have to travel a long distance to search for water. Even many communities easily can offer palm wine to visitors but not the bathing or drinking water because of water scarcity. Regarding the factors behind the hindrance of rural economic growth Shah (2001) and Michael (2000) have highlighted unemployment, scarcity of portable and needful agricultural water, wasteful man-hours during search of needful water. Mkpado, Arene and Idu (2010), had highlighted the importance of education in growth of rural community. Konyebagu (2010), discussed that the Federal Government of Nigeria has had a framework for water and water sector development but problems arise because of continuity. Many researchers have done work on Surface and Groundwater Quality of Enugu Urban Areas and Nsukka Urban Area of Enugu State, all based in Nigeria (Ezemonye, 2009; Ibeziako, 1985; Mong, 1984; Nnodu \& Ilo, 2000; Udeze, 1988). But there is a gap in research for wide spread utilization of water for sustainable livelihood and poverty reduction related to rural water delivery and bottom-up management process of water delivery. Also, evaluation technique related to the effectiveness and efficiency of utilization of rural water delivery of LEEMP for dry season homestead agriculture is called for.

\section{Material and Method}

By using Names in hat balloting method for each community studies, this study adopted Simple Random Survey (SRS). Further, Simple random sampling was used for the study. Initially, Enugu and Imo states were selected, and then three LGAs from each were selected as locations for collecting samples. 20 farmers were selected from each location to a total amount of 180 farmers. Focus Group Discussion (FGD) and Key Informant Interview were the mainly used methods for collecting data through a structured questionnaire. Reliability testing was done using the Cronbach Alpha Technique. Result showed a reliability coefficient of 0.74 . The pilot study was done in Nkanu West and East LEEMP water support benefitting farmers. Regression analysis, marginal analysis model and Chi-square test were used for analyses purposes.

\subsection{Regression Analysis Model}

For purposes of this study the implicit multiple regression function would be:

$\mathrm{Y}=\mathrm{f}\left(\mathrm{X}_{1}, \mathrm{X}_{2}, \mathrm{X}_{3} \ldots \mathrm{Xn}, \mathrm{U}\right)$, and

the explicitly function as:

$\mathrm{Y}=\mathrm{b}_{0}+\mathrm{b}_{1} \mathrm{X}_{1}+\mathrm{b}_{2} \mathrm{X}_{2}+\mathrm{b}_{3} \mathrm{X}_{3} \ldots \mathrm{bnXn}+\mathrm{U}$

Where,

$\mathrm{Y}=$ Income (inN)

$\mathrm{X}_{1}=$ quantitative use of CDD support investment (water volume in Litres)

$\mathrm{X}_{2}=$ daily farm man-days (in hours)

$\mathrm{X}_{3}=$ farm support services (farm expenditures in $\mathrm{N}$ )

bs = coefficients which measure the elasticity

$\{\mathrm{U}=\mathrm{Hs}, \mathrm{Ag}, \mathrm{Ms}, \mathrm{Pa}, \mathrm{Cn}, \mathrm{Rb}$ and $\mathrm{Ed}\}$

$\mathrm{Hs}=$ household size

$\mathrm{Ag}=$ age

Ms = marital status

$\mathrm{Pa}=$ Position among community leader

$\mathrm{Cn}=$ number of children

$\mathrm{Rb}=$ religion

$\mathrm{Ed}=$ level of education

\subsection{Marginal Analysis Model}

The condition of least cost production, according to Bishop and Toussaint (1958) and Taylor (2009), was that the marginal products of the inputs are proportional to the prices of the input: $\left(\Delta \mathrm{Y}_{1} / \Delta \mathrm{X}_{1}\right) / \mathrm{Px}_{1}=\left(\Delta \mathrm{Y}_{1} / \Delta \mathrm{X}_{2}\right) / \mathrm{Px}_{2}=$ - - $\left(\Delta \mathrm{Y}_{1} / \Delta \mathrm{X}_{\mathrm{n}}\right) / \mathrm{Px}_{\mathrm{n}}$

Where: $\Delta \mathrm{Y}_{1}=$ volume of water used from the LEEMP water delivery support borehole (in Litres),

$\Delta \mathrm{X}_{1}=$ Man-hours spent in fetching water from LEEMP support borehole (in man-days).

$\Delta \mathrm{X}_{2}=$ Man-hour spent in fetching water from the stream undesired alternative(in man-

days),

$\mathrm{Px}_{1}=$ price of a man- day for fetching water from water delivery support borehole (in $\mathrm{N}$ ),

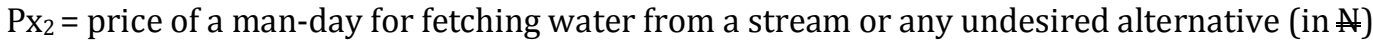

$\mathrm{Px}_{\mathrm{n}}=$ price of any other undesired alternative source of water delivery (in

$\Delta \mathrm{Y}_{1} / \Delta \mathrm{X}_{1}=$ marginal product of LEEMP water delivery support

$\Delta \mathrm{Y}_{1} / \Delta \mathrm{X}_{2}=$ marginal product of stream water delivery

But, the dry- season Marginal Revenue Function to compare efficiency of input prices is:

$$
\mathrm{PX}=\frac{\mathrm{Py} \Delta \mathrm{Y}}{\Delta \mathrm{X}}
$$




\subsubsection{Revenue}

- Fishery income $=$ Sales - Variable cost of inputs (cost of fingering, water, feed, transport, Labour and interest rate),

- Poultry Income = Sales - Variable cost of inputs (cost of day-old chick, inoculation, Vaccination, water, feed, transport, labour and interest rate).

\section{Results}

\begin{tabular}{|c|c|c|}
\hline School Training & Number of Respondents & Percentage (\%) \\
\hline No Education & 24 & 13 \\
\hline F. S. L. C. (Primary) & 27 & 48 \\
\hline WASC/TCII & 52 & 29 \\
\hline OND/NCE & 38 & 21 \\
\hline Degree & 18 & 21 \\
\hline Total & 180 & 180 \\
\hline
\end{tabular}

Table 1: Distribution of Respondent Water Users According to Educational Levels Source: Field Study

\begin{tabular}{|c|c|c|c|c|}
\hline $\begin{array}{c}\text { Age } \\
\text { Bracket }\end{array}$ & $\begin{array}{c}\text { Size } \\
\mathbf{1 - 3}\end{array}$ & $\begin{array}{c}\text { Size } \\
\mathbf{4 - 6}\end{array}$ & $\begin{array}{c}\text { Size } \\
\mathbf{7 - 9}\end{array}$ & $\begin{array}{c}\text { Size } \\
\text { Total }\end{array}$ \\
\hline $22-35$ & $15(8.3 \%)$ & $30(16.7 \%)$ & $5(2.8 \%)$ & $50(27.8 \%)$ \\
\hline $36-49$ & $33(18.3 \%)$ & $59(32.8 \%)$ & $9(5 \%)$ & $101(56.1 \%)$ \\
\hline $50-63$ & $10(5.6 \%)$ & $16(8.9 \%)$ & $3(1.6 \%)$ & $29(16.1 \%)$ \\
\hline Total & $58(32.2 \%)$ & $105(58.4 \%)$ & $17(9.4 \%)$ & $180(100 \%)$ \\
\hline
\end{tabular}

Table 2: Distribution of Household Size According to Age Brackets

Source: Field Survey

\begin{tabular}{|c|c|c|c|c|c|}
\hline $\begin{array}{c}\text { Distance } \\
\text { To } \\
\text { Site }(\mathbf{k m})\end{array}$ & $\begin{array}{c}\text { Duration } \\
\text { of water } \\
\text { Delivery }\end{array}$ & $\begin{array}{c}\text { Number of } \\
\text { Farmers } \\
\text { Used (litres) }\end{array}$ & $\begin{array}{c}\text { Total Farmers' } \\
\text { Weekly Water }\end{array}$ & $\begin{array}{c}\text { Percentage } \\
\text { Water Used } \\
\text { in farm (\%) }\end{array}$ & $\begin{array}{c}\text { Average Daily H/hold } \\
\text { Water Used } \\
\text { (litres) }\end{array}$ \\
\hline $0.09-0.04$ & $15-29 \mathrm{Min}$ & $75(41.7 \%)$ & 72,200 & 45 & 212 \\
\hline $0.05-0.09$ & $30-44$ & $59(32.8 \%)$ & 50,800 & 32 & 201 \\
\hline $1.0-1.4$ & $45-59$ & $23(2.8 \%)$ & 18,600 & 12 & 198 \\
\hline $1.5-1.9$ & $60-74$ & $19(10.6 \%)$ & 14,000 & 9 & 198 \\
\hline $2.0-2.4$ & $75-89$ & $4(2.2 \%)$ & 4,000 & 2 & 198 \\
\hline Total & $90 \mathrm{~min}$ & $180(100 \%)$ & 159,000 & 100 & 1,007 \\
\hline
\end{tabular}

Table 3: Distribution of Farmers According to Distance, Duration and Level of Water Use Source: Field Survey

\begin{tabular}{|c|c|c|c|}
\hline $\begin{array}{c}\text { Mark-up of water } \\
\text { Vendor Intensity } \\
\text { Per Litre sales (N) }\end{array}$ & $\begin{array}{c}\text { Water Cost } \\
\text { at 10/25L }\end{array}$ & $\begin{array}{c}\text { Transport } \\
\text { Cost }\end{array}$ & $\begin{array}{c}\text { Total Cost } \\
\text { Per Litre }\end{array}$ \\
\hline $0.5($ at $0.51 \mathrm{~km})$ & 0.4 & - & 0.9 \\
\hline $0.4($ at $1.21 \mathrm{~km})$ & 0.4 & 0.2 & 1.0 \\
\hline $0.3($ at $1.61 \mathrm{~km}$ & 0.4 & 0.4 & 1.1 \\
\hline $0.2($ at $2.01 \mathrm{~km})$ & 0.4 & 0.6 & 1.2 \\
\hline 0.1 (at $2.41 \mathrm{~km})$ & 0.4 & 0.8 & 1.3 \\
\hline
\end{tabular}

Table 4: Distribution of Cost of Water Delivery Source: Field Survey

\begin{tabular}{|c|c|c|c|c|c|c|}
\hline $\begin{array}{c}\text { Proportion } \\
\text { of Water Used } \\
\text { By Distance } \\
\text { (k) }\end{array}$ & $\begin{array}{c}\text { Average } \mathrm{H} / \text { hold } \\
\text { Volume of water } \\
\text { Used } \\
\text { (X in Litres) }\end{array}$ & $\begin{array}{c}\text { Cost Per } \\
\text { Litre } \\
(\mathrm{Px})\end{array}$ & $\begin{array}{l}\text { Total } \\
\text { Product } \\
\text { Cost(A) } \\
\text { k(YPy) }\end{array}$ & $\begin{array}{c}\text { Marginal } \\
\text { Cost } \\
(\Delta \mathrm{XPx})\end{array}$ & $\begin{array}{c}\text { Total } \\
\text { Revenue } \\
\text { @ N25/25L } \\
\text { k(XPx) } \\
\end{array}$ & $\begin{array}{c}\text { Marginal } \\
\text { Revenue } \\
\text { (DYPy) }\end{array}$ \\
\hline $\begin{array}{l}0.45 \text { (at } \\
0.51 \mathrm{~km})\end{array}$ & 212 & 0.9 & 86 & - & 95 & - \\
\hline 0.32 (at1.21km) & 201 & 1.0 & 64 & 22 & 64 & 31 \\
\hline $\begin{array}{l}0.09 \text { (at } \\
2.01 \mathrm{~km})\end{array}$ & 189 & 1.2 & 20 & 6 & 17 & 7 \\
\hline $\begin{array}{l}0.02 \text { (at } \\
2.41 \mathrm{~km})\end{array}$ & 189 & 1.3 & 5 & 154 & 13 & 4 \\
\hline
\end{tabular}

Table5: Distribution of Water Delivery Marginal Cost and Marginal Revenue Source: Field Survey 


\begin{tabular}{|c|c|c|c|c|c|c|c|c|}
\hline Yr & $\begin{array}{c}\text { Volume of Water } \\
\text { used } Y_{1} \\
\text { (Litres in milliom) }\end{array}$ & $\Delta \mathbf{Y}_{1}$ & $\begin{array}{c}\text { Man-days } \\
\left.\text { vendor( } \mathrm{X}_{1}\right) \\
\text { (LEEMP) }\end{array}$ & $\Delta \mathbf{X}_{1}$ & $\begin{array}{c}\text { Man-days } \\
\text { vendor }\left(\mathrm{X}_{2}\right) \\
\text { (Stream) }\end{array}$ & $\Delta \mathbf{X}_{2}$ & $\begin{array}{c}\text { Farm time Saved } \\
\text { (Man-days) }\end{array}$ & $\begin{array}{l}\text { Daily Timeliness per unit } \\
\text { of LEEMP water } \\
\text { delivery (hr: min) }\end{array}$ \\
\hline 2008 & 2.8370 & & 4,962 & & 9,764 & & 4,802 & $41 \min$ \\
\hline 2009 & 3.1918 & 0.35 & 5,056 & 94 & 9,878 & 114 & 4,822 & $42 \mathrm{~min}$ \\
\hline 2010 & 3.5464 & 0.35 & 5,126 & 70 & 9,958 & 80 & 4,832 & $42 \mathrm{~min}$ \\
\hline 2011 & 3.9010 & 0.35 & 5,186 & 60 & 10,034 & 76 & 4,848 & $42 \mathrm{~min}$ \\
\hline 2012 & 4.2558 & 0.35 & 5,222 & 36 & 10,094 & 60 & 4,872 & $42 \mathrm{~min}$ \\
\hline Total & 17.7320 & & 25,552 & & 49,728 & & 24,176 & 1hr:45min1hr:45min \\
\hline
\end{tabular}

Table 6: Distribution of Time Saved, Marginal Product and Marginal Cost of Water Delivery Source: Field Survey

\begin{tabular}{|c|c|c|c|c|c|c|c|c|c|}
\hline \multirow{2}{*}{$\begin{array}{c}\begin{array}{c}\text { Model } \\
\text { (Income) }\end{array} \\
\text { Variable }\end{array}$} & \multicolumn{3}{|c|}{ Linear Model } & \multicolumn{3}{|c|}{ Semi-log } & \multicolumn{3}{|c|}{ Double-log Model } \\
\hline & Coefficient & T-statistics & Pro.b & Coefficient & $\begin{array}{c}\text { T- } \\
\text { statistics }\end{array}$ & Pro.b & Coefficient & T-statistics & Pro.b \\
\hline $\begin{array}{c}\text { Qty of Water } \\
\text { used }\end{array}$ & 4.97 & 26.4 & Ns & -1.2 & -32.0 & Ns & 1.99 & 50.8 & Ns \\
\hline $\begin{array}{l}\text { Man-days } \\
\text { (LEEMP) }\end{array}$ & -7067.85 & -88.1 & Ns & -4089201.0 & -25.3 & Ns & 0.12 & 7.3 & Ns \\
\hline $\begin{array}{l}\text { Man-days } \\
\text { (Stream) }\end{array}$ & 9067.03 & 83.7 & Ns & 8203811.0 & 26.0 & Ns & -0.20 & -6.3 & Ns \\
\hline $\begin{array}{c}\text { Farm } \\
\text { Expenditure }\end{array}$ & 1.27 & 51.5 & Ns & 8545140.0 & 29.8 & Ns & Ns & -0.87 & Ns \\
\hline $\begin{array}{c}\text { Household } \\
\text { Size } \\
\end{array}$ & 0.80 & 0.1 & $\mathrm{Xxx}$ & 39439.4 & 2.828 & Ns & -0.00 & -2.8 & Ns \\
\hline Age & -0.21 & -0.3 & $\mathrm{Xxx}$ & -6439.4 & -0.7 & Ns & 0.00 & 0.7 & Ns \\
\hline $\begin{array}{c}\text { Leadership } \\
\text { position }\end{array}$ & -20.07 & -2.3 & Ns & -22009.0 & -1.4 & Ns & 0.00 & 1.4 & Ns \\
\hline $\begin{array}{c}\text { Number of } \\
\text { children }\end{array}$ & 9.39 & 1.0 & Ns & -13262.8 & -1.5 & Ns & 0.00 & 1.5 & Ns \\
\hline Religion & -18.58 & -1.9 & Ns & -16162.4 & -1.2 & Ns & 0.00 & 1.2 & Ns \\
\hline $\begin{array}{c}\text { Level of } \\
\text { Education }\end{array}$ & -14.16 & -2.5 & Ns & -11415.5 & -1.3 & Ns & 0.00 & 1.3 & Ns \\
\hline $\begin{array}{l}\text { Marital } \\
\text { status }\end{array}$ & -20.96 & -4.3 & Ns & -77543.5 & -14.6 & Ns & 0.00 & 14.6 & Ns \\
\hline $\mathrm{R}$-square & & 1.0000 & & & 0.9997 & & & 1.0000 & \\
\hline $\begin{array}{c}\text { Adjusted R- } \\
\text { square }\end{array}$ & & 1.0000 & & & 0.9994 & & & 1.0000 & \\
\hline Prob $>F$ & & 0.0000 & & & 0.0000 & & & 0.0000 & \\
\hline Root MSE & & 19.368 & & & 2690.5 & & & 0.00027 & \\
\hline
\end{tabular}

Table 7: Parameter Estimate of Multiple Regression Models by Ordinary Least Square

Method Used In Evaluating Dry Season Fishery Income NB: $(X x x)=$ Figures Significant at $P \leq 0.05$; Source: Analysis of Output Data by Research

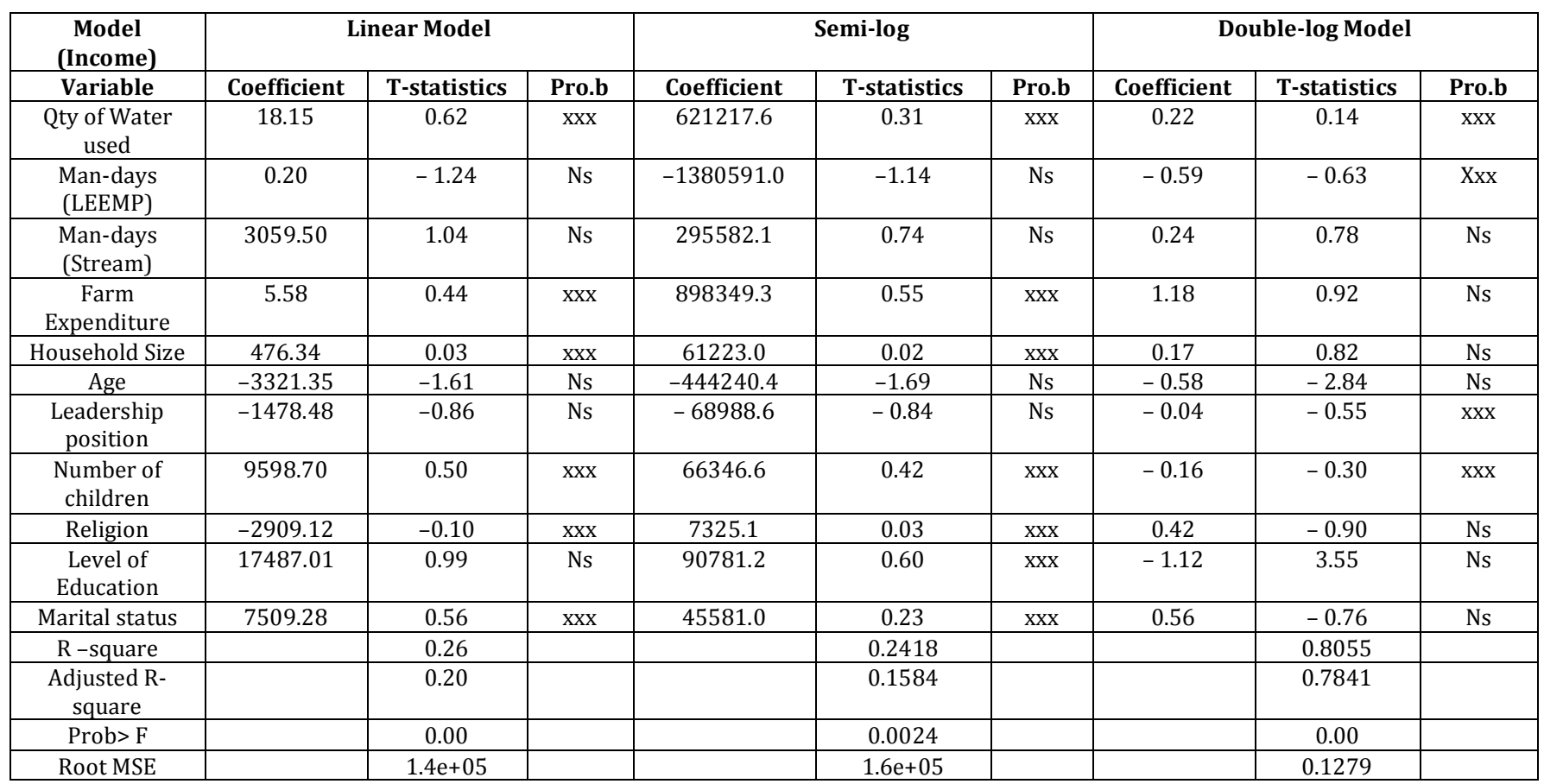

Table 8: Parameter Estimate of Multiple Regression Models by Ordinary Least Square

Method Used in Evaluating Dry Season Poultry Incom NB: (xxx) = figures significant at $p \leq 0.05$; Source: Analysis of output Data by Researcher. 


\section{Discussion}

About $42 \%$ of the farmers had higher level of educational empowerment, $29 \%$ of them had secondary school education. $27 \%$ had only primary education while $13 \%$ had no education. Therefore, $40 \%$ of the respondents were rather to be carried along during the participatory sensitization activities of the demand supportive organizations. This is in line with the DFID in Enugu State that Constructive Participation is still low (DFID, 2005). Majority of the farmers came from age group of 36-49 with low number of dependants. This finding negates the study of Chaudhry, Malik and Hasan 2009; Pablo and Jose, 2009, that showed much dependants among peasant farmers. The regression analysis of Socio-economic Influencing Factors of Marital status, number of children, Leadership position, religion and level of education on utilization of dry season water and on credit support for poultry and fishery income showed that economic statistic of the number of children, the leadership position and religion significantly $(\mathrm{p} \leq 0.05)$ influenced poultry credit while household size and age significantly $(\mathrm{p} \leq 0.05)$ influenced income from fishery. The $89 \%$ of the water used were from a distance of $1.5 \mathrm{~km}(3 \mathrm{~km}$ to and fro) and by a greater number, $87.9 \%$ of farmers. This revelation shows that LEEMP has made water delivery to be nearer and easy for the respondent farmers. The Focus Group information showed that 25 litres water jerry-can sells at $\$ 10$ in most water delivery gates. The vendors most often sell the same 25 litres at $\$ 25$. A mark-up cost of $\$ 10$ was pending due to the cost of efforts (intensity value addition of water delivery) and cost of distance covered (transportation).Chambers, 2000; Oza, 2004; Beister, Stewart and Jones, 1980 found that water vendor intensity, as in focused labour or capital to produce large quantity of output, decreases inversely with distance. The intensity mark-up was reduced from 50 kobo per liter to 10 kobo (table 4). When taking delivery of water above a distance of $2.41 \mathrm{~km}$ (above $4.82 \mathrm{~km}$; to and fro) it was very costly to the farmer, who bore the cost of vendor water delivery, since the marginal cost $\$ 15$ outweighed the marginal revenue $\$ 13$ (table 5 ) at that distance, translating into diminishing return. The poverty reduction was in switching over from stream undesired alternative to LEEMP delivery support. The marginal incremental ratio of LEEMP agricultural water delivery was 10:6. (table 6).The ratio was determined as follows:The price of a ma-day of fetching water is currently $\$ 1000$, (ENADEP, 2012).

Therefore, $\left(\Delta \mathrm{Y}_{1} / \Delta \mathrm{X}_{1}\right) / \mathrm{Px}_{1}=(0.35 \mathrm{~m} / 36) / 1000$

$$
\begin{aligned}
& =350,000 / 36 \times 1 / 1000 \\
& =9.72 \\
& \underline{\underline{L}} 10
\end{aligned}
$$

Similarly, $\quad\left(\Delta \mathrm{Y}_{1} / \Delta \mathrm{X}_{2}\right) / \mathrm{Px}_{2}=(.35 \mathrm{~m} / 60) / 1000$

$$
\begin{aligned}
& =350,000 / 60 \times 1 / 1000 \\
& =5.85 \\
& \underline{\perp L} 6
\end{aligned}
$$

The marginal product of LEEMP water delivery support was higher than the stream undesired alternative by a ratio $10: 6$. Also, the daily timeliness of LEEMP water delivery was 42 minutes (table 6 ) on the average, but generally it was between 40 minutes and 50 minutes due to variation in the levels of water use in the farm.

\section{Conclusion and Recommendations}

This study has highlighted about many methods to reduce the rural livelihood challenges in terms of scarcity of portable and needful agricultural water, wasteful man-hours during search of needful water, and inefficient use of resources to bridge the off-season gap in rural income generation. Learning- by- doing activities of Community Driven Development (CDD) strategy is very helpful for solving inadequate mobilization capacity in most rural programme. Many development partners State Agricultural Development Programmes (ADPs), Non-government organizations, Local government councils, State government, Federal government and the World Bank like should work together. Dry season livestock fattening can be used to control high cost of food and to engender rural employment in order to control rural urban migration of youths and control the off-season gap in rural income generation.

\section{References}

i. Afatyo, R. (2005) "People Make a Difference", LEEMP Observer, Federal Ministry of Environment Nigeria, Pilot Issue PP. 4-9

ii. Beister, A. Stewart, A. D. and D. I. Jones (1980), “Amplitude and Intensity”, Applied Physics, Schaun's Vocational and Technical Series, London: McGraw Hill Book Company.

iii. Chambers, R. (2000), "PRA Tools", Comparative Fact Files of India and Gujarat, India: Development Support Centre (dsc).

iv. Chaudhury, I. S., Malik, S. and A. Hasan (2009), "The Impact of Socio-Economic and Demographic Variables on Poverty": A Village Study. The Lahore Journal of Economics 14:1:pp 39 - 68

v. DFID, (2005)"Public Forum at the Enugu Benchmarking", Quarterly Newsletter of Enugu DFID Partnership Programme, DFID Enugu News Vol. 4 No.2 April - June2005

vi. Enugu state MOA (2013), Inventory of Fish farmers, Animal Production Department, Ministry of Agriculture, Enugu.

vii. Enugu state PRS/SEED (2004), Getting to the Root of Poverty: SEED Document, Enugu Ministry of Human Development and Poverty reduction.

viii. Eze, D. (2007), "The Story of Akama Water Project”, Empowerment News Abuja: LEEMP SPSU P. 9.

ix. Ezemonye, M. N. (2009), Surface and Ground Water Quality of Enugu Urban Area; Unpublished PhD Thesis, Department of Geography, university of Nigeria Nsukka. 
x. FPSU (2004), Report of the Workshop for Multi-disciplinary Implementation Team (MIT) Members from LEEMP, Imo, Enugu and Bayelsa States at Owerri Nigeria, October 26 to November 6.

xi. FPSU (2006), Report of Workshop on Strategic Communication Development Training at Zaria; Organised by LEEMP FPSU, November 20 to December 1.

xii. FPSU and MacMatts Consultants (2006), Workshop Training Module for MFT by MacMatts Consultants Ltd Owerri, Venue at Umuahia Nigeria, March 27- April 13.

xiii. Ibeziakor, M. N. (1985), Residual Water Demand in Enugu Urban Area of Nigeria; Unpublished M. Sc Thesis, University of Nigeria Nsukka.

xiv. Imo state MOA (2013), Inventory of Fish farmers, Animal Production Department, Ministry of Agriculture, Owerri.

xv. Konyebagu, R. (2010), "Editorial Review of the Proposed Federal Government Road Map for Water", Waterfront, Lagos Nigeria; Nigerian Water and Sanitation Association (NIWASA). 12 $2^{\text {th }}$ Issue, P. 01

xvi. Michael, M., Adams, B. and M. Haris (2000), Poverty and System Research in Dry Land, London: Gate Keeper Series No. 94.

xvii. Mkpado, M., Arene, C. J. and M. A. Idu (2010), "Effect of Membership Homogeneity on the Performance of Agricultural Micro-Credit Groups in Rural Credit Markets in Nigeria”, Medwell Journals - PJSS, Vol. \&, No. 4 PP 304 $-307$.

xviii. Mong, E. A. (1984), Urban Water Pollution in Aba, Nigeria; Unpublished B. Sc. Thesis, University of Nigeria.

xix. Nnodu, V. C. and I. C. Ilo (2000), Comparative Quality Evaluation of Source of Domestic Water Supply in Enugu Urban Area; Environmental Review, Vol. 3 No. 1 PP. 215 - 231.

xx. Okwor, C. E. (2001), "Roles of Agricultural Development in Poverty Reduction in Nigeria" ENADEP Focus, Enugu State ADP Vol. No. 1 PP. 7 - 8.

xxi. Oza, S. (2004), "Participatory Rural Appraisal: Participatory Water-shed Development Programme”, Report of Training Workshop on Community Driven Development (CDD) Approach for Multi-Disciplinary facilitation Team (MFT), in Owerri Nigeria; Indian dsc, October 26 to November 6.

xxii. Pablo, B. and S Jose Maria (2009), Access to land and Rural Poverty in Developing Countries: Theory and Evidence from Guatemara, University of Politecnica de Madrid. MPRA

xxiii. Paper No. 13365, Available online at http:/mpra.ub.uni-muenchen.de/13365/posted 12 February 2009/14:29

xxiv. Shah, A. C (2001), "Shoulder Tapping: In the Hand of the People”, Report of the Workshop on

xxv. Operationalizing Participatory Approaches in Natural Resource Management, dsc Gujarat, October 16 - 17.

xxvi. Udeze, M. C. (1988), River Water Pollution Enugu Urban Area; Unpublished M. Sc Thesis, University of Nigeria Nsukka.

xxvii. Ugwuoke, J. O. (2006), LEEMP Background", Enugu LEEMP News: LEEMP SPSU. Vol. 2 No. 2. June, P 2.

xxviii. UNICEF Nigeria (2012), 'Water Supply and Sanitation,' safe water supply can support sustainable Livelihoods and provide for school children, a review of UNICEF mandated International Drinking Water Supply and Sanitation Decade (1981 - 1990) 